Sains Malaysiana 47(11)(2018): 2821-2829

http://dx.doi.org/10.17576/jsm-2018-4711-25

\title{
Multiplex Real-Time PCR Detection of Respiratory Viruses in Lower Respiratory Tract Infections in Children
}

(Multipleks PCR Masa Sebenar untuk Pengesanan Jangkitan Virus Pernafasan dalam Saluran Pernafasan Bahagian Bawah bagi Kanak-Kanak)

\section{Zetti Zainol Rashid*, Pei Chuen Lee, Umi Kalsom Ali, Muttaqillah Najihan} ABDUL SAMAT \& SWEE FONG TANG

\begin{abstract}
Acute respiratory infections cause significant morbidity and mortality in children. Several new respiratory viruses have been identified and co-detection of multiple viruses is commonly reported. This is part of a prospective study which aims to detect respiratory viruses by multiplex molecular method and conventional methods. Nasopharyngeal aspirate specimens were taken from hospitalised children aged less than 5 years with lower respiratory tract infections. These were tested using viral culture, immunofluorescence and Seegene Anyplex ${ }^{T M}$ II RV16 real-time polymerase chain reaction. From 102 samples, 69 (67.6\%) were positive by PCR, 12 (11.8\%) positive by culture method and 13 (12.7\%) positive by IF. A single viral pathogen was detected in 48 samples (47.1\%), while 21 samples (20.6\%) had co-detection of 2 to 4 viral pathogens. Respiratory syncytial virus (RSV) was most common, detected in 17 samples (16.7\% of all samples), followed by adenovirus and rhinovirus in 16 (15.7\%), respectively. Bocavirus was detected in 15, enterovirus in 15, influenza A in 8 and parainfluenza-4 in 4 samples, with highest occurrences in co-detection $(12 / 15,10 / 15,5 / 8$ and 3/4, respectively). RSV was the least likely detected in co-detection (3/17). In PCR-positive samples, 54/69(78.3\%) were patients aged up to 24 months. Molecular methods detect more viral aetiologies than conventional methods, with simultaneous detection of multiple respiratory viruses. More sensitive, specific and rapid tools to determine aetiological agents could be incorporated into diagnostic algorithms of respiratory tract infections. Interpretations, significance, and applicability in clinical practice could be further explored, particularly for patients up to 2 years old.
\end{abstract}

Keywords: Infections; molecular; multiplex; PCR; respiratory viruses

ABSTRAK

Jangkitan pernafasan akut mengakibatkan morbiditi dan mortaliti yang ketara pada kanak-kanak. Beberapa virus pernafasan yang baru telah dikenal pasti dan pengesanan beberapa virus secara serentak biasa dilaporkan. Kajian ini adalah sebahagian daripada kajian prospektif bertujuan untuk mengesan virus pernafasan menggunakan kaedah molekul multipleks dan kaedah konvensional. Spesimen aspirat nasofarinks diambil daripada kanak-kanak berumur kurang daripada 5 tahun yang dimasukkan ke hospital kerana jangkitan saluran pernafasan bahagian bawah. Pengujian adalah menggunakan pengkulturan virus, imunofluoresen dan reaksi rantai polimerase masa sebenar menggunakan Seegene Anyplex ${ }^{T M}$ II RV16. Daripada 102 sampel, 69 (67.6\%) positif PCR, 12 (11.8\%) positif dengan kaedah kultur virus dan $13(12.7 \%)$ positif dengan imunofluoresen. Patogen virus tunggal dikesan dalam 48 sampel (47.1\%), manakala 21 sampel (20.6\%) mempunyai pengesanan bersama 2 hingga 4 patogen virus. Virus pernafasan sinsitium (RSV) paling banyak dikesan, iaitu dalam 17 sampel (16.7\% daripada semua sampel), diikuti oleh adenovirus dan rhinovirus dalam 16(15.7\%) masing-masing. Bocavirus dikesan dalam 15, enterovirus dalam 15, influenza A dalam 8 dan parainfluenza-4 dalam 4 sampel dengan kes tertinggi dalam pengesanan bersama (12/15, 10/15, 5/8 dan 3/4 masing-masing). RSV paling sedikit dikesan dalam pengesanan bersama (3/17). Dalam sampel positif PCR, 54/69 (78.3\%) adalah pesakit berusia sehingga 24 bulan. Kaedah molekul mengesan lebih banyak virus daripada kaedah konvensional dengan pengesanan serentak pelbagai virus pernafasan. Kaedah yang lebih sensitif, khusus dan cepat untuk menentukan agen penyebab boleh dimasukkan ke dalam algoritma diagnosis jangkitan saluran pernafasan. Tafsiran keputusan ujian dan kegunaannya dalam amalan klinikal boleh diterokai dengan lebih lanjut, terutama untuk pesakit berusia sehingga 2 tahun.

Kata kunci: Jangkitan; molekul; multipleks; PCR; virus pernafasan

\section{INTRODUCTION}

Acute respiratory infections cause significant morbidity and mortality in infants and young children (Bryce et al. 2005; Shay et al. 1999). A systematic analysis estimated that in 2010, 11.9 million episodes of severe and 3.0 million episodes of very severe acute lower respiratory infections resulted in hospital admissions in young children globally (Nair et al. 2013). It was estimated that in 2010 there were 
120 million episodes of pneumonia in children younger than 5 years and 1.3 million episodes of pneumonia led to death in 2011 (Walker et al. 2013). Pneumonia is a major cause of illness and death among children aged less than 5 years of age (Rudan et al. 2004). A study on lower respiratory tract infections in hospitalized children in Malaysia reported overall mortality rate of $1.3 \%$ (Nathan et al. 2014).

Several new viruses have been identified in respiratory infections, such as human metapneumovirus (van den Hoogen et al. 2001), bocavirus (Allander et al. 2005), coronaviruses SARS (Ksiazek et al. 2003), NL63 (van der Hoek et al. 2004) and HKU1 (Woo et al. 2005). Molecular techniques enable detection of viruses not detected by conventional methods, such as viral culture and immunofluorescence, particularly the newer viruses. Codetection of more than one virus is increasingly recognised and commonly reported. Currently available molecular methods enable simultaneous detection of multiple viruses and may offer advantages over the conventional methods. This study aims to detect respiratory viruses by real-time multiplex molecular or polymerase chain reaction (PCR) method as well as conventional methods using viral culture and immunofluorescence.

\section{MATERIALS AND METHODS}

This study was part of a prospective study conducted in the Paediatric wards, UKM Medical Centre from 2014 to 2015. This 900-bedded tertiary centre is located in Kuala Lumpur, the capital of Malaysia. Nasopharyngeal aspirate specimens taken from hospitalised children aged less than 5 years, with symptoms and signs of lower respiratory tract infections. Demographic variables including age, gender and ethnic group were recorded from the laboratory information system. Results of viral cultures, IF and multiplex PCR were analysed. Ethics approval was obtained from the UKM Research and Ethics Committee before starting the study.

\section{SPECIMEN COLLECTION}

Nasopharyngeal aspirate (NPA) specimens were obtained within $24 \mathrm{~h}$ of admission as part of routine procedure for investigations of respiratory tract infection. The specimens were placed in ice or cold packs and transported to the viral culture laboratory. Specimens received out of working hours were kept in $2-4^{\circ} \mathrm{C}$ and processed during the next working day. Specimens which did not fulfill the requirements for specimen collection, transport and storage requirements were excluded.

\section{SPECIMEN PREPARATION}

Specimens received were vortexed for $15 \mathrm{~s}$ to remove all contents from a swab into the transport media and filtered with 0:45 $\mu \mathrm{m}$ micro-filter to isolate the bacteria and fungi that could contaminate cell culture. Filtered specimens were then aliquoted into 2 tubes. One tube was used for respiratory viral culture and immunoflourescence (IF) testing. The second tube was used for nucleic acid extraction and real-time PCR.

\section{VIRAL CULTURE AND IMMUNOFLOURESCENCE (IF) TEST}

Processing specimens for viral culture and IF were done according to the standard operating procedures as part of the routine laboratory diagnostics. The filtered specimen for viral culture were inoculated into cell culture (Madin Darby Canine Kidney (MDCK) and Hep-2) and incubated at $37^{\circ} \mathrm{C}(5 \% \mathrm{CO} 2)$. Cytopathic effects (CPE) in cell culture were observed every working day. IF tests were done using LIGHT DIAGNOSTICS $^{\text {TM }}$ Respiratory Panel Viral Screening \& Identification IFA Kit. IF panels include Influenza A, Influenza B, Parainfuenza 1, 2, 3, Adenovirus and RSV. IF tests were done on cultures with positive CPE. Positive IF results were reported. Cultures with negative IF were re-incubated until the end of incubation period. On day 10 of incubation, subculture and IF were performed on specimens without CPE. Positive IF result were reported. Specimens with negative IF were re-incubated until the end of incubation period, as per standard procedure for the different viruses and repeat IF test were performed and reported.

\section{MULTIPLEX REAL-TIME PCR METHOD}

The second tubes from the filtered specimen were sent to the PCR laboratory. Nucleic acid extraction was done using Nimbus (Hamilton ${ }^{\circledR}$ ) instrument for automated extraction. The reagents used were STARMag 96 Virus extraction kit for RV16 and cDNA Synthesis Automix (Seegene) for reverse transcription step in RV16, according to manufacturer protocol. The assay used in this study was the Anyplex ${ }^{\mathrm{TM}}$ II RV16 test from Seegene, Korea. It is based on Seegene's proprietary $\mathrm{DPO}^{\mathrm{TM}}$ and $\mathrm{TOCE}^{\mathrm{TM}}$ technologies, which enables complex multiplexing in a single fluorescence channel, with simultaneous detection of 16 common respiratory viruses in a single real-time PCR, from a wide range of specimen types, such as nasopharyngeal aspirates and swabs, or bronchoalveolar lavage samples. The PCR is carried out using CFX96 ${ }^{\mathrm{TM}}$ (Bio-Rad) instrument. The assay turn-around time (TAT) is less than $4 \mathrm{~h}$ and provides rapid respiratory disease screening. For results with more than one pathogen detection, semi-quantitative results could be generated $(+,++,+++)$ based on the cycle threshold values. The kit has CE Mark and In-Vitro Diagnostics (IVD) certification.

A positive case is defined as the presence of any viral pathogen detected in the respiratory sample of a given patient, by PCR and/or culture method. A patient is considered to have a single viral infection if only one pathogen is detected. In patients where more than one pathogen is detected, patients were said to have codetection of viruses.

The pathogens detected are listed in the two panels of mastermixes as follows: 
Panel A: Adenovirus (AdV), Influenza A virus (FluA), Influenza B virus (FluB), Parainfluenza 1 virus (PIV1), Parainfluenza 2 virus (PIV2), Parainfluenza 3 virus (PIV3), Parainfluenza 4 virus (PIV4), Rhinovirus A/B/C (HRV), Internal control (IC).

Panel B: Respiratory syncytial virus A (RSVA), Respiratory syncytial virus B (RSV B), Bocavirus 1/2/3/4 (HBoV), Coronavirus 229E (CoV 229E), Coronavirus NL63 (CoV NL63), Coronavirus OC43 (CoV OC43), Metapneumovirus (MPV), Enterovirus (HEV), IC.

\section{RESULTS}

A total of 102 nasopharyngeal aspirate samples were tested. Samples from male patients constitute a total of 67 while 35 samples were from female patients. A total of 69 samples $(67.6 \%)$ were positive by PCR, 12 samples $(11.8 \%)$ positive by culture method and 13 samples (12.7\%) positive by IF. A single viral pathogen was detected in $48 / 69$ positive samples $(47.1 \%$ of all samples), while 21 (20.6\% of all samples) had co-detection of 2 to 4 viral pathogens. The result summary for Anyplex ${ }^{\mathrm{TM}}$ II RV16 is shown in Table 1.

Respiratory syncytial virus (RSV) was the most common aetiology detected in 17 samples (16.7\% of all samples), followed by adenovirus and rhinovirus in $16(15.7 \%)$, respectively. Bocavirus was detected in 15 , enterovirus in 15, influenza $A$ in 8 and parainfluenza-4 in 4 samples, with the highest occurrences in co-detection $(12 / 15,10 / 15,5 / 8$ and $3 / 4$ respectively). Results of the
TABLE 1. Summary of results for Anyplex ${ }^{\text {TM }}$ II RV 16

\begin{tabular}{lcc}
\hline & $\begin{array}{c}\text { Number of } \\
\text { samples }\end{array}$ & $\%$ \\
\hline Total PCR-positive samples & $69 / 102$ & $67.6 \%$ \\
Total negative samples & $33 / 102$ & $32.4 \%$ \\
Single infection & $48 / 69$ & $47.1 \%$ \\
$\quad$ Co-detection & $21 / 69$ & $20.6 \%$ \\
Co-detection of 2 viruses & $16 / 21$ & \\
Co-detection of 3 viruses & $3 / 21$ & \\
Co-detection of 4 viruses & $2 / 21$ & \\
\hline
\end{tabular}

respiratory viruses detected by the three methods are shown in Table 2. The relatively underdiagnosed or underreported human metapneumovirus was detected in 2 samples, while coronavirus NL63 and OC43 were detected in 1 sample each. Results of the respiratory viruses detected stratified by age groups are shown in Table 3. In all PCR-positive samples, $38 / 69(55.1 \%)$ were patients aged up to 12 months and $54 / 69(78.3 \%)$ were patients aged up to 24 months. For most of the pathogens, more than $80 \%$ of positive cases were patients aged up to 24 months. The semi-quantitative results $(+,++,+++)$ that were generated by the system for samples with co-detection are shown in Table 4. For two out of 21 samples, the results of conventional methods agreed with the higher pathogen quantitation by PCR. Results of the Anyplex ${ }^{\mathrm{TM}}$ II RV16, culture and IF were noted to be discordant for four samples and the final results concluded are shown in Table 5.

TABLE 2. Respiratory viruses detected by Anyplex ${ }^{\text {TM }}$ II RV16, culture and IF methods

\begin{tabular}{|c|c|c|c|c|c|c|}
\hline & $\begin{array}{l}\text { Culture } \\
\text { positive } \\
n=102\end{array}$ & $\begin{array}{l}\text { IF positive } \\
n=102\end{array}$ & $\begin{array}{c}\text { PCR } \\
\text { positive } \\
n=102\end{array}$ & $\begin{array}{c}\text { No. of single } \\
\text { detection } \\
n=69\end{array}$ & $\begin{array}{c}\text { No.of } \\
\text { occurrence in } \\
\text { co-detection }\end{array}$ & $\begin{array}{l}\% \text { in co- } \\
\text { detection }\end{array}$ \\
\hline \multicolumn{7}{|l|}{$\begin{array}{l}\text { Anyplex }{ }^{\mathrm{TM}} \text { II RV16 } \\
\text { Panel A }\end{array}$} \\
\hline Adenovirus & 2 & 2 & 16 & 8 & 9 & 52.9 \\
\hline Influenza A virus & 3 & 3 (1 PCR negative) & 8 & 3 & 5 & 62.5 \\
\hline Influenza B virus & 1 & 1 & 2 & 2 & 0 & \\
\hline Parainfluenza 1 virus & & - & - & - & - & \\
\hline Parainfluenza 2 virus & & - & - & - & - & \\
\hline Parainfluenza 3 virus & & - & - & - & - & \\
\hline Parainfluenza 4 virus & & N/A & 4 & 1 & 3 & 75 \\
\hline Rhinovirus A/B/C & & N/A & 16 & 10 & 6 & 37.5 \\
\hline \multicolumn{7}{|l|}{$\begin{array}{l}\text { Anyplex }{ }^{\mathrm{TM}} \text { II RV16 } \\
\text { Panel B }\end{array}$} \\
\hline Respiratory syncytial virus A & 6 & 7 (1 culture negative) & 17 & 14 & 3 & 17.6 \\
\hline Respiratory syncytial virus B & & & - & - & - & \\
\hline Bocavirus $1 / 2 / 3 / 4$ & & N/A & 15 & 3 & 12 & 80 \\
\hline Metapneumovirus & & N/A & 2 & 1 & 1 & 50 \\
\hline Coronavirus 229E & & N/A & - & - & - & \\
\hline Coronavirus NL63 & & N/A & 1 & 1 & 0 & \\
\hline Coronavirus OC43 & & N/A & 1 & 1 & 0 & \\
\hline Enterovirus & & N/A & 15 & 5 & 10 & 66.7 \\
\hline Total individual virus detected & $\begin{array}{c}12 \\
(11.8 \%)\end{array}$ & $\begin{array}{c}13 \\
(12.7 \%)\end{array}$ & 97 & $\begin{array}{c}48 \\
(69.6 \%)\end{array}$ & N/A & N/A \\
\hline
\end{tabular}


TABLE 3. Age groups and respiratory viruses detected

\begin{tabular}{|c|c|c|c|c|c|}
\hline & $\begin{array}{c}\text { 0-6 } \\
\text { months }\end{array}$ & $\begin{array}{c}\text { 7-12 } \\
\text { months }\end{array}$ & $\begin{array}{l}\text { 13-24 } \\
\text { months }\end{array}$ & $\begin{array}{l}25-60 \\
\text { months }\end{array}$ & Total \\
\hline \multicolumn{6}{|l|}{$\begin{array}{l}\text { Anyplex }{ }^{\mathrm{TM}} \text { RV16 } \\
\text { Panel A: }\end{array}$} \\
\hline Adenovirus (AdV) & 0 & 9 & 5 & 2 & 16 \\
\hline Influenza A virus (Flu A) & 1 & 2 & 2 & 3 & 8 \\
\hline Parainfluenza 1 virus (PIV1) & 0 & 0 & 0 & 0 & 0 \\
\hline Parainfluenza 2 virus (PIV2) & 0 & 0 & 0 & 0 & 0 \\
\hline Parainfluenza 3 virus (PIV3) & 0 & 0 & 0 & 0 & 0 \\
\hline Parainfluenza 4 virus (PIV4) & 1 & 1 & 1 & 1 & 4 \\
\hline Rhinovirus A/B/C (HRV) & 6 & 5 & 2 & 3 & 16 \\
\hline Respiratory syncytial virus B (RSV B) & 0 & 0 & 0 & 0 & 0 \\
\hline Bocavirus 1/2/3/4 (HBoV) & 3 & 4 & 6 & 2 & 15 \\
\hline Metapneumovirus (MPV) & 1 & 1 & 0 & 0 & 2 \\
\hline Coronavirus 229E (CoV 229E) & 0 & 0 & 0 & 0 & 0 \\
\hline Coronavirus NL63 (CoV NL63) & 0 & 0 & 0 & 1 & 1 \\
\hline Coronavirus OC43 (CoV OC43) & 0 & 0 & 0 & 1 & 1 \\
\hline Enterovirus (HEV) & 6 & 5 & 3 & 1 & 15 \\
\hline Total number of PCR-positive samples & 20 & 18 & 16 & 15 & 69 \\
\hline
\end{tabular}

TABLE 4. Respiratory viruses co-detection and semi-quantitative results

\begin{tabular}{|c|c|c|c|}
\hline & Semi-quantitative results of Anyplex ${ }^{\mathrm{TM}}$ II RV16 & Viral culture & IF \\
\hline \multirow[t]{16}{*}{ Co-detection of 2 viruses } & $\mathrm{AdV}+, \mathrm{HEV}+$ & - & - \\
\hline & $\mathrm{AdV}+, \mathrm{HEV}++$ & - & - \\
\hline & $\mathrm{AdV}++$, Flu $\mathrm{A}++$ & - & - \\
\hline & $\mathrm{AdV}++, \mathrm{HRV}+$ & - & - \\
\hline & $\mathrm{AdV}+++, \mathrm{MPV}+$ & AdV & AdV \\
\hline & AdV++ , HRV + & - & - \\
\hline & Flu $\mathrm{A}+++, \mathrm{HEV}+$ & - & - \\
\hline & Flu $\mathrm{A}+++, \mathrm{HBoV}+$ & - & - \\
\hline & $\mathrm{HBoV}+, \mathrm{HEV}++$ & - & - \\
\hline & $\mathrm{HBoV}+, \mathrm{RSV} \mathrm{A}++$ & - & - \\
\hline & $\mathrm{HBoV}+, \mathrm{RSV} \mathrm{A}++$ & - & RSV \\
\hline & $\mathrm{HBoV}++, \mathrm{HEV}+++$ & - & - \\
\hline & $\mathrm{HRV}++, \mathrm{HBoV}++$ & - & - \\
\hline & PIV4 + , HBoV ++ & - & - \\
\hline & PIV4 +, Flu A ++ & - & - \\
\hline & $\mathrm{RSVA}+++, \mathrm{HEV}++$ & - & - \\
\hline \multirow[t]{3}{*}{ Co-detection of 3 viruses } & $\mathrm{AdV}+, \mathrm{HRV}+++, \mathrm{HBoV}+$ & - & - \\
\hline & FLU A ++ , HBoV +++, $\mathrm{HEV} \mathrm{+}$ & RSV & RSV \\
\hline & $\mathrm{HRV}++, \mathrm{HBoV}+++, \mathrm{HEV}+$ & - & - \\
\hline \multirow[t]{2}{*}{ Co-detection of 4 viruses } & $\mathrm{AdV}+, \mathrm{HRV}+, \mathrm{HBoV}++, \mathrm{HEV}++$ & - & - \\
\hline & $\mathrm{PIV} 4+, \mathrm{AdV}++, \mathrm{HBoV}++, \mathrm{HEV}+$ & - & - \\
\hline $\mathrm{AdV}=$ adenovirus & RSV A = respiratory syncytial virus A & & \\
\hline Flu $\mathrm{A}=$ influenza $\mathrm{A}$ virus & RSV B $=$ respiratory syncytial virus B & & \\
\hline Flu B = influenza B virus & $\mathrm{HBoV}=$ bocavirus $1 / 2 / 3 / 4$ & & \\
\hline PIV1 = parainfluenza 1 virus & MPV $=$ metapneumovirus & & \\
\hline PIV2 = parainfluenza 2 virus & CoV 229E = Coronavirus 229E & & \\
\hline PIV3 = parainfluenza 3 virus & CoV NL63 = Coronavirus NL63 & & \\
\hline PIV4 = parainfluenza 4 virus & CoV OC43 = Coronavirus OC43 & & \\
\hline $\mathrm{HRV}=$ rhinovirus $\mathrm{A} / \mathrm{B} / \mathrm{C}$ & $\mathrm{HEV}=$ Enterovirus & & \\
\hline
\end{tabular}


TABLE 5. Discordant results in four samples

\begin{tabular}{ccccc}
\hline Samples & Semi-quantitative PCR results & Viral culture & IF & Results concluded \\
\hline 1 & Negative & Flu A & Flu A & Positive Flu A \\
2 & HBoV,+ RSV A ++ & Negative & RSV & Positive RSV \\
3 & RSV A ++ & Flu A & Flu A & Positive Flu A \\
4 & Flu A,++ HBoV,$+++ H E V+$ & RSV & RSV & Positive RSV \\
\hline
\end{tabular}

Flu A = influenza A virus

RSV A = respiratory syncytial virus A

$\mathrm{HBoV}=$ bocavirus $1 / 2 / 3 / 4$

$\mathrm{HEV}=$ enterovirus

\section{DISCUSSION}

Lower respiratory tract infections cause significant morbidity and mortality in infants and young children and impose a significant burden on healthcare services globally (Bryce et al. 2005; Nair et al. 2013). Relatively few studies on respiratory infections and the aetiologies had been conducted in this country over the years (Jason et al. 2016; Khor et al. 2012; Ong et al. 1982; Zamberi et al. 2003). Molecular methods have high sensitivity thus yielding not only increased detection of viral pathogens, but with detection of multiple viruses, which was not usually observed with conventional methods. Co-detection of more than one virus is now commonly reported. However, respiratory viruses such as rhinoviruses (Jacobs et al. 2013; Royston et al. 2016), bocavirus (Allander et al. 2005; Broccolo et al. 2015; Guido et al. 2016), enteroviruses (Jason et al. 2016; Royston et al. 2016) and coronaviruses (Lee et al. 2014; van der Hoek et al. 2004; Woo et al. 2005) and their roles as respiratory pathogens are less well-established. These may be further investigated and described by studies using the currently available molecular techniques.

A wide range of positivity had been reported in studies using molecular methods. In this study, overall positivity rate was $67.6 \%$, with a single viral pathogen detected in 48 samples (47.1\% of all samples or $69.6 \%$ of all positive samples). The positivity rate is quite comparable to other findings in this region such as Vietnam $60.9 \%$ (Yoshida et al. 2013), Korea 66\% (Cho et al. 2013) and Taiwan $60.2 \%$ (Lee et al. 2015). Another study in Malaysia found that 2708 of 10269 samples $(26.4 \%)$ were positive for respiratory viruses. RSV accounted for $70.6 \%$ of all positive cases by IF and culture, followed by parainfluenza (13.2\%), influenza (11.0\%) and adenovirus (5.2\%) (Khor et al. 2012). The differences in the rates reported are due to patient populations, age range, symptoms, platforms or methods of detection and panels of respiratory viruses included in the different methods.

Most studies report RSV, rhinovirus and adenovirus as the most common causes of respiratory tract infections. RSV was reported as the most common viral cause of pneumonia and bronchiolitis in children aged less than 5 years (Nair et al. 2010). This study detected RSV in 17 samples (16.7\% of all samples), followed by adenovirus and rhinovirus in 16 each (15.7\%, respectively) among the most common. Influenza B was detected in 2 samples, while Parainfluenza-1, 2 and 3 were not detected in these patient samples. Metapneumovirus was positive in 2 samples, and relatively new coronaviruses NL63 and OC43 was also positive in one sample each.

Co-detection of more than one pathogen reported ranged from $12 \%$ to more than $40 \%$ (Brand et al. 2011; García-Arroyo et al. 2016; Rehder et al. 2015; Roh et al. 2008). In this study, 21 samples (20.6\% of all samples or $30.4 \%$ of all positive samples) had more than 1 viral pathogen, which is within the expected range. Bocavirus was detected in 15 and enterovirus in 15 samples, influenza $A$ in 8 and parainfluenza- 4 in 4 samples, with the highest occurrences in co-detection $(12 / 15,10 / 15,5 / 8$ and $3 / 4$, respectively). RSV was the least likely detected in co-detection (3/17). Rehder et al. (2015) reported $12 \%$ co-detection in the 235 positive patients and similarly the most common viral aetiologies were adenovirus and RSV. A study in Spain reported a higher rate of multiple detection, in 30/80 samples (37.5\%) (García-Arroyo et al. 2016). A study in Taiwan found 130/216 samples were positive by molecular method $(60.2 \%)$, where 25 of these $(19.2 \%)$ consisted of co-detection. The picornaviruses (rhinovirus and enterovirus) were most prevalent, found in $24.6 \%$ followed by RSV in $13.8 \%$ (Lee et al. 2015). A study in the Netherlands found that $73 \%$ of 177 patients was positive for at least one respiratory pathogen, in which 47 (26.6\%) were co-detection. RSV (36.6\%) and human rhinovirus (24.0\%) were most frequently detected (Huijskens et al. 2012). A study in Australia reported that 740 out of 817 patients $(90.6 \%)$ were positive, while $423(51.8 \%)$ had coinfection with virus and bacteria. Haemophilus influenzae was the predominant bacteria in cases of virus and bacteria co-infection (O’Grady et al. 2016).

There are conflicting reports on whether co-detection is associated with more severe respiratory disease. Multiple detection of respiratory pathogens were not found to be associated with severity of disease in some studies (Asner et al. 2014; Brand et al. 2011; Gagliardi et al. 2013; Lee et al. 2015). While in other studies, multiple detection were found to be associated with increased risk of moderate or severe disease or increased mortality (Aberle et al. 2005; Rehder et al.2015). The interpretations and significance of detection of multiple viruses remains to be described and determined. It may also be difficult to differentiate between 
prolonged shedding and current replication. The presence or detection of some viruses in normal or asymptomatic individuals had been reported. Rhinovirus RNA could be detected in nasal mucus for several weeks after infection and some respiratory viruses such as rhinoviruses, human coronaviruses and bocavirus are also detected in asymptomatic children (Advani et al. 2012; Debiaggi et al. 2012; Jartti et al. 2004).

PCR detects viral nucleic acids and the cycle threshold $(\mathrm{Ct})$ values of the real-time PCR may be used to generate the semi-quantitative results. Viral loads may be useful to predict infections as opposed to the presence or persistence of organisms. The semi-quantitative results that were calculated $(+,++,+++)$ for samples with co-detection are shown in Table 4 , where the higher pathogen quantitation by PCR correlated with IF results in 2 samples. However, interpretations remain difficult particularly when there are discrepancies with the results of conventional methods, as shown in Table 5. Even though viral culture is generally regarded as the gold standard, detection by PCR which is known to have very high specificity indicates the presence of viral nucleic acids. Garcia-Arroyo et al. (2016) reported that in some specimens, two different molecular methods detected different viruses. These findings again raise the question on the aetiology of infection and the dilemma in reporting results. A lot more need to be further evaluated regarding semi-quantitative results and their significance, which is not yet established for respiratory viral infections.

Seegene multiplex assays have undergone several evaluations (Bibby et al. 2011; Bruijnesteijn van Coppenraeta et al. 2010; Gharabaghi et al. 2011; Roh et al. 2008). These assays had better detection rate compared to viral culture method and was able to detect co-infections (Bruijnesteijn van Coppenraeta et al. 2010; Roh et al. 2008). In a comparison of four multiplex PCR assays with IF and viral culture in children, the Seegene kit was found to be the most sensitive in detecting most targets (Gharabaghi et al. 2011). In another study, the RV15 kit was found to be comparable to in-house PCR system (Bibby et al. 2011). For the current version of Seegene Anyplex ${ }^{\mathrm{TM}}$ II RV16, comparison was made with 2 other multiplex RT-PCR assays for the detection of respiratory viruses in 201 respiratory samples and showed similar performance (Yun et al. 2017). Anyplex ${ }^{\mathrm{TM}}$ II RV16 was done with RV12 assays in parallel, in 365 respiratory samples and comparable results were found (Huh et al. 2014). Other studies on Seegene Anyplex ${ }^{\mathrm{TM}}$ II RV16 done comparing RV16, RV15 and XTAG RVP (Kim et al. 2013) while Cho et al. (2013) compared RV16, RV15 and culture methods. They reported good overall sensitivity for most respiratory viruses and very high overall specificity. Other recent molecular methods available for respiratory viruses had been assessed and compared (Reddington et al. 2013; Zumla et al. 2014). Comparisons had been made in 300 samples, between 4 multiplex panels namely Biofire FilmArray RP, Genmark eSensor RVP, Luminex XTAG RVPv1 and Luminex XTAG RVP fast multiplex (Popowitch et al. 2013). Couturier et al. (2013) evaluated the FilmArray® Respiratory Panel.
Salez et al. (2015) evaluated the Cepheid Xpert® Flu/RsV $\mathrm{XC}$ assay for rapid detection of influenza $\mathrm{A}$, influenza $\mathrm{B}$ and RSV.

Cost consideration is a major hindrance for the rather slow implementation despite evidence of high performance, sensitivity and specificity of the tests. Pooling or batch testing is usually required or practically feasible, as opposed to single sample or small batch testing which would be quicker and more favourable, particularly for smaller laboratories. Current molecular techniques are also limited by the relative lack of standards for laboratory quality assurance, for benchmarking and comparison among the different molecular techniques and various manufacturers. Other limitations include the technical difficulties, PCR inhibition due to various reasons, sample factors, extraction factors, variability of respiratory viruses and primer designs among others. Obvious advantages include avoidance of time-consuming conventional methods and other costly tests. Knowledge of viral aetiology could potentially help in reducing nosocomial transmission, isolation of positive patients and potentially reduce length of hospitalization. It also allows the choice to avoid antibiotics, even though there may be concerns about bacterial co-infection. In a study of the impact of multiplex real-time PCR, detection of viral aetiology was associated with discontinuation of antibiotics in 6 of 14 children (43\%) and overall 18 children $(67 \%)$ were managed correctly without antibiotics after virus detection (Mayer et al. 2017). It was suggested that PCR had an impact on appropriate therapy for clinically defined viral infections.

\section{CONCLUSION}

Findings from this study provide more information on the epidemiology of viral respiratory tract infections, especially with regards to the gap in diagnosis as well as identification of the newer viruses by using multiplex real-time PCR. Currently available molecular methods provide detection of more viral aetiologies than conventional methods of culture and IF, with advantages of higher sensitivity and specificity over the conventional methods. In addition, simultaneous detection of multiple respiratory viruses is increasingly recognised and needs to be further explored in terms of interpretations, significance, applicability, association with severity of disease and clinical impact. More sensitive and specific tools to determine the aetiological agents such as molecular methods could be incorporated into the diagnostic algorithm of respiratory tract infections and to ascertain their utility in clinical practice, particularly in patients aged up to 2 years old.

\section{ACKNOWLEDGEMENTS}

This project was supported by the Research University Grant, project code GUP-2013-018. We wish to thank NeoScience Sdn Bhd for providing Seegene Anyplex ${ }^{\mathrm{TM}}$ II RV16 kits and technical support, especially Lydiana $\mathrm{Ng}$ Xin Rui. Our thanks to Haslina Mahbob and Nor Maslini 
Ismail, staff in Tissue Culture Unit, Department of Medical Microbiology \& Immunology, UKM Medical Centre, Kuala Lumpur, for their invaluable assistance and commitment. We also wish to thank Professor Dr Zaleha Abdullah Mahdy, the Dean, Faculty of Medicine, UKM. The authors declare that they have no conflict of interest.

\section{REFERENCES}

Aberle, J.H., Aberle, S.W., Pracher, E., Hutter, H.P., Kundi, M. \& Popow-Kraupp, T. 2005. Single versus dual respiratory virus infections in hospitalized infants: Impact on clinical course of disease and interferon-gamma response. Pediatr. Infect. Dis. J. 24(7): 605-610.

Advani, S., Sengupta,A., Forman, M., Valsamakis, A. \& Milstone, A. 2012. Detecting respiratory viruses in asymptomatic children. Pediatr. Infect. Dis. J. 31(12): 1221-1226.

Allander, T., Tammi, M.T., Eriksson, M., Bjerkner, A., TiveljungLindell, A. \& Andersson, B. 2005. Cloning of a human parvovirus by molecular screening of respiratory tract samples. Proc. Natl. Acad. Sci. U.S.A 102: 12891-12896.

Asner, S.A., Rose, W., Petrich, A., Richardson, S. \& Tran, D.J. 2014. Is virus coinfection a predictor of severity in children with viral respiratory infections? Clin. Microbiol. Infect. 21(3): 264.e1-264.e6.

Bibby, D.F., McElarney, I., Breuer, J. \& Clark, D.A. 2011. Comparative evaluation of the Seegene Seeplex RV15 and real-time PCR for respiratory virus detection. J. Medical Virology 83: 1469-1475.

Brand, H.K., de Groot, R., Galama, J.M., Brouwer, M.L., Teuwen, K., Hermans, P.W., Melchers, W.J. \& Warris, A. 2011. Infection with multiple viruses is not associated with increased disease severity in children with bronchiolitis. Pediatr. Pulmonol. 47: 393-400.

Broccolo, F., Falcone, V., Esposito, S. \& Toniolo, A. 2015. Human bocaviruses: Possible etiologic role in respiratory infection. J. Clin. Virol. 72: 75-81.

Bruijnesteijn van Coppenraet, L.E.S., Swanink, C.M.A., van Zwet, A.A., Nijhuis, R.H.T., Schirm, J., Wallinga, J.A. \& Ruijs, G.J.H.M. 2010. Comparison of two commercial molecular assays for simultaneous detection of respiratory viruses in clinical samples using two automatic electrophoresis detection systems. J. Virological Methods 169: 188-192.

Bryce, J., Boschi-Pinto, C., Shibuya, K. \& Black, R.E. 2005. The WHO Child Health Epidemiology Reference Group WHO estimates of the causes of death in children. Lancet 365: 1147-1152.

Cho, C.H., Chulten, B., Lee, C.K., Nam, M.H., Yoon, S.Y., Lim, C.S., Cho, Y. \& Kim, Y.K. 2013. Evaluation of a novel realtime RT-PCR using TOCE technology compared with culture and Seeplex RV15 for simultaneous detection of respiratory viruses. J. Clin. Virol. 57(4): 338-342.

Couturier, M.R., Barney, T., Alger, G., Hymas, W.C., Stevenson, J.B., Hillyard, D. \& Daly, J.A. 2013. Evaluation of the FilmArray ${ }^{\circledR}$ Respiratory Panel for clinical use in a large children>s hospital. J. Clin. Lab. Anal. 27(2): 148-154.

Debiaggi, M., Canducci, F., Ceresola, E.R. \& Clementi, M. 2012. The role of infections and coinfections with newly identified and emerging respiratory viruses in children. Virol.J. 9: 247.

Gagliardi, T.B., Paula, F.E., Iwamoto, M.A., Proença-Modena, J.L., Santos, A.E., Camara, A.A., Cervi, M.C., Cintra, O.A. \& Arruda, E. 2013. Concurrent detection of other respiratory viruses in children shedding viable human respiratory syncytial virus. J. Med. Virol. 85(10): 1852-1859.

García-Arroyo, L., Prim, N., Martí, N., Roig, M.C., Navarro, F. \& Rabella, N. 2016. Benefits and drawbacks of molecular techniques for diagnosis of viral respiratory infections. Experience with two multiplex PCR assays. J. Med. Virol. 88(1): 45-50

Gharabaghi, F., Hawan, A., Drews, S.J. \& Richardson, S.E. 2011. Evaluation of multiple commercial molecular and conventional diagnostic assays for the detection of respiratory viruses in children. Clin. Microbiol. Infect. 17: 1900-1906.

Guido, M., Tumolo, M.R., Verri, T., Romano, A., Serio, F., De Giorgi, M., De Donno, A., Bagordo, F. \& Zizza, A. 2016. Human bocavirus: Current knowledge and future challenges. World J. Gastroenterol. 22(39): 8684-8697.

Huh, H.J., Park, K.S., Kim, J.Y., Kwon, H.J., Kim, J.W., Ki, C.S. \& Lee, N.Y. 2014. Comparison of the Anyplex(TM) II RV16 and Seeplex(®) RV12 ACE assays for the detection of respiratory viruses. Diagn. Microbiol. Infect. Dis. 79(4): 419-421.

Huijskens, E.G., Biesmans, R.C., Buiting, A.G., Obihara, C.C. \& Rossen, J.W. 2012. Diagnostic value of respiratory virus detection in symptomatic children using real-time PCR. Virology Journal 9: 276.

Jacobs, S.E., Lamson, D.M., St George, K. \& Walsh, T.J. 2013. Human rhinoviruses. Clin. Microbiol. Rev. 26(1): 135-162.

Jartti, T., Lehtinen, P., Vuorinen, T., Koskenvuo, M.\& Ruuskanen, O. 2004. Persistence of rhinovirus and enterovirus RNA after acute respiratory illness in children. J. Med. Virol. 72: 695-699.

Jason, T.W.Y., Ramli, N., Yusof, M.A., Vengataraman, N., Hussin, H. \& Abdul Latif, Z. 2016. Epidemiological and clinical features of enteroviral acute lower respiratory tract infections in hospitalized paediatric patients in a Malaysian tertiary center. Med. J. Malaysia 71(5): 264-268.

Khor, C.S., I-Ching, S., Hooi, P.S., Quek, K.F. \& Chan, Y.F. 2012. Epidemiology and seasonality of respiratory viral infections in hospitalized children in Kuala Lumpur, Malaysia: A retrospective study of 27 years. BMC Pediatrics 12: 32.

Kim, H.K., Oh, S.H., Yun, K.A., Sung, H. \& Kim, M.N. 2013. Comparison of Anyplex II RV16 with the XTAG respiratory viral panel and Seeplex RV15 for detection of respiratory viruses. J. Clin. Microbiol. 51(4): 1137-1141.

Ksiazek, T.G., Erdman, D., Goldsmith, C.S., Zaki, S.R., Peret, T., Emery, S., Tong, S., Urbani, C., Comer, J.A., Lim, W., Rollin, P.E., Dowell, S.F., Ling, A.E., Humphrey, C.D., Shieh, W.J., Guarner, J., Paddock, C.D., Rota, P., Fields, B., DeRisi, J., Yang, J.Y., Cox, N., Hughes, J.M., LeDuc, J.W., Bellini, W.J., Anderson, L.J. \& SARS Working Group. 2003. A novel coronavirus associated with severe acute respiratory syndrome. N. Engl. J. Med. 348: 1953-1966.

Lee, C.Y., Chang, Y.F., Lee, C.L., Wu, M.C., Ho, C.L. \& Chang, Y.C. 2015. Molecular viral epidemiology and clinical characterization of acute febrile respiratory infections in hospitalized children in Taiwan. J. Med. Virol. 87(11): 1860-1866

Lee, J. \& Storch, G.A. 2014. Characterization of human coronavirus OC43 and human coronavirus NL63 infections among hospitalized children $<5$ years of age. Pediatr. Infect. Dis. J. 33(8): 814-20.

Mayer, L.M., Kahlert, C., Rassouli, F., Vernazza, P. \& Albrich, W.C. 2017. Impact of viral multiplex real-time PCR on management of respiratory tract infection: A retrospective 
cohort study. Pneumonia 9: 4. DOI 10.1186/s41479-0170028-z.

Nair, H., Nokes, D.J., Gessner, B.D., Dherani, M., Madhi, S.A., Singleton, R.J., O’Brien, K.L., Roca, A., Wright, P.F., Bruce, N., Chandran,A., Theodoratou, E., Sutanto,A., Sedyaningsih, E.R., Ngama, M., Munywoki, P.K., Kartasasmita, C., Simões, E.A., Rudan, I., Weber, M.W. \& Campbell, H. 2010. Global burden of acute lower respiratory infections due to respiratory syncytial virus in young children: A systematic review and meta-analysis. Lancet 375: 1545-1555.

Nair, H., Simões, E.A., Rudan, I., Gessner, B.D., AzzizBaumgartner, E., Zhang, J.S., Feikin, D.R., Mackenzie, G.A., Moïsi, J.C., Roca, A., Baggett, H.C., Zaman, S.M., Singleton, R.J., Lucero, M.G., Chandran, A., Gentile, A., Cohen, C., Krishnan, A., Bhutta, Z.A., Arguedas, A., Clara, A.W., Andrade, A.L., Ope, M., Ruvinsky, R.O., Hortal, M., McCracken, J.P., Madhi, S.A., Bruce, N., Qazi, S.A., Morris, S.S., El Arifeen, S., Weber, M.W., Scott, J.A., Brooks, W.A., Breiman, R.F., Campbell, H. \& Severe Acute Lower Respiratory Infections Working Group. 2013. Global and regional burden of hospital admissions for severe acute lower respiratory infections in young children in 2010: A systematic analysis. Lancet 381: 1380-1390.

Nathan, A.M., Rani, F., Lee, R.J.Y., Zaki, R., Westerhout, C., Sam, I.C., Lum, L.C.S. \& de Bruyne, J. 2014. Clinical risk factors for life-threatening lower respiratory tract infections in children: A retrospective study in an urban city in Malaysia. PLOS ONE 9(10): e111162. doi:10.1371/journal. pone. 0111162 .

O'Grady, K.F., Grimwood, K., Sloots, T.P., Whiley, D.M., Acworth, J.P., Phillips, N., Goyal, V. \& Chang, A.B. 2016. Prevalence, codetection and seasonal distribution of upper airway viruses and bacteria in children with acute respiratory illnesses with cough as a symptom. Clin. Microbiol. Infect. 22(6): 527-534.

Ong, S.B., Lam, K.L. \& Lam, S.K. 1982. Viral agents of acute respiratory infections in young children in Kuala Lumpur. Bull. World Health Organ. 60: 137-140.

Popowitch, E.B., O’Neill, S.S. \& Miller, M.B. 2013.Comparison of the Biofire FilmArray RP, Genmark eSensor RVP, Luminex xTAG RVPv1, and Luminex xTAG RVP fast multiplex assays for detection of respiratory viruses.J.Clin.Microbiol. 51(5): 1528-1533.

Reddington, K., Tuite, N., Barry, T., O'Grady, J. \& Zumla, A. 2013. Advances in multiparametric molecular diagnostics technologies for respiratory tract infections. Curr. Opin. Pulm. Med. 19(3): 298-304.

Rehder, K.J., Wilson, E.A., Zimmerman, K.O., Cunningham, C.K. \& Turner, D.A. 2015. Detection of multiple respiratory viruses associated with mortality and severity of illness in children. Pediatr. Crit. Care Med. 16(7): e201-e206.

Roh, K.H., Kim, J., Nam, M.H., Yoon, S., Lee, C.K., Lee, K., Yoo, Y., Kim, M.J. \& Cho, Y. 2008. Comparison of the seeplex reverse transcription pcr assay with the r-mix viral culture and immunofluorescence techniques for detection of eight respiratory viruses. Annals. of Clin. Lab. Science 38(1): 41-46.

Royston, L. \& Tapparel, C. 2016. Rhinoviruses and respiratory enteroviruses: Not as simple as ABC. Viruses 8: 16.

Rudan, I., Tomaskovic, L., Boschi-Pinto, C. \& Campbell, H. 2004. Global estimate of the incidence of clinical pneumonia among children under five years of age. Bull. World Health Organ. 82: 895-903.
Salez, N., Nougairede, A., Ninove, L., Zandotti, C., de Lamballerie, X. \& Charrel, R.N. 2015. Prospective and retrospective evaluation of the Cepheid Xpert ${ }^{\circledR}$ Flu/RSV $\mathrm{XC}$ assay for rapid detection of influenza A, influenza $\mathrm{B}$, and respiratory syncytial virus. Diagn. Microbiol. Infect. Dis. 81(4): 256-258.

Shay, D.K., Holman, R.C., Newman, R.D., Liu, L.L., Stout, J.W. \& Anderson, L.J. 1999. Bronchiolitis associated hospitalizations among US children, 1980-1996. JAMA 282: 1440-1446.

van den Hoogen, B.G., de Jong, J.C., Groen, J., Kuiken, T., de Groot, R., Fouchier, R.A. \& Osterhaus, A.D. 2001. A newly discovered human pneumovirus isolated from young children with respiratory tract disease. Nat. Med. 7: 719-724.

van der Hoek, L., Pyrc, K., Jebbink, M.F., Vermeulen-Oost, W., Berkhout, R.J., Wolthers, K.C., Wertheim-van Dillen, P.M., Kaandorp, J., Spaargaren, J. \& Berkhout, B. 2004. Identification of a new human coronavirus. Nat. Med. 10: 368-373.

Walker, C.L., Rudan, I., Liu, L., Nair, H., Theodoratou, E., Bhutta, Z.A., O'Brien, K.L., Campbell, H. \& Black, R.E. 2013. Global burden of childhood pneumonia and diarrhoea. The Lancet 381: 1405-1416

Woo, P.C., Lau, S.K., Chu, C.M., Chan, K.H., Tsoi, H.W., Huang, Y., Wong, B.H., Poon, R.W., Cai, J.J., Luk, W.K., Poon, L.L., Wong, S.S., Guan, Y., Peiris, J.S. \& Yuen, K.Y. 2005. Characterization and complete genome sequence of a novel coronavirus, coronavirus HKU1, from patients with pneumonia. J. Virol. 79: 884-895.

Yoshida, L.M., Suzuki, M., Nguyen, H.A., Le, M.N., Dinh Vu, T., Yoshino, H., Schmidt, W.P., Nguyen, T.T., Le, H.T., Morimoto, K., Moriuchi, H., Dang, D.A. \& Ariyoshi, K. 2013. Respiratory syncytial virus co-infection and paediatric lower respiratory tract infection. Eur. Respir. J. 42: 461-469.

Yun, S.G., Kim, M.Y., Choi, J.M., Lee, C.K., Lim, C.S., Cho, Y. \& Suh, I.B. 2017. Comparison of three multiplex PCR assays for detection of respiratory viruses: Anyplex II RV16, AdvanSure RV, and Real-Q RV. J. Clin. Lab. Anal. https:// doi.org/10.1002/jcla.22230.

Zamberi, S., Zulkifli, I. \& Ilina, I. 2003. Respiratory viruses detected in hospitalised paediatric patients with respiratory infections. Med.J. Malaysia 58: 681-687.

Zumla, A., Al-Tawfiq, J.A., Enne, V.I., Kidd, M., Drosten, C., Breuer, J., Muller, M.A., Hui, D., Maeurer, M., Bates, M., Mwaba, P., Al-Hakeem, R., Gray, G., Gautret,P.,Al-Rabeeah, A.A., Memish, Z.A. \& Gant, V. 2014. Rapid point of care diagnostic tests for viral and bacterial respiratory tract infections--needs, advances, and future prospects. Lancet Infect. Dis. 14(11): 1123-1135.

Zetti Zainol Rashid*, Umi Kalsom Ali \& Muttaqillah Najihan Abdul Samat

Department of Medical Microbiology \& Immunology

Faculty of Medicine

Universiti Kebangsaan Malaysia Medical Centre

Jalan Yaacob Latif

56000 Kuala Lumpur, Federal Territory

Malaysia

Pei Chuen Lee \& Swee Fong Tang

Department of Paediatrics

Faculty of Medicine 
Universiti Kebangsaan Malaysia Medical Centre Jalan Yaacob Latif

56000 Kuala Lumpur, Federal Territory

Malaysia
*Corresponding author; email: zetti@ppukm.ukm.edu.my

Received: 24 May 2018

Accepted: 3 July 2018 